\title{
Mediating Role of Absorptive Capacity on the Relationship between Foreign Direct Investment and Local Firm's Performance
}

\author{
M. D. Wanjere, X. N. Iraki, M. Ogutu, and M. Kinoti
}

\section{ABSTRACT}

\begin{abstract}
There is little documentation on the role of absorptive capacity on the relationship between FDI and performance of firms. This paper investigates the mediating role of absorptive capacity on the relationship between FDI and performance of manufacturing firms in Kenya. The population of study comprised 100 companies registered with Kenya Association of Manufacturers that had over 10 percent foreign ownership as at the time of data collection in 2019. The respondents were the CEOs of organization or their designated officers. The study used a structured questionnaire to collect primary data. The respondent were required to indicate how the introduction of FDI impacted on organizations capital flow, advanced production technology, marketing expertise and management knowhow. They were also to indicate the extent their Organisation had invested in absorptive capacity and the effect absorptive capacity had on the relationship between FDI and local firm performance. Descriptive and inferential statistics were both used to analyze the data. The results revealed that absorptive capacity has statistically significant mediating effect on the relationship between FDI and firm performance. This imply that an incremental change in the absorptive capacity would generate growth in company's performance. As such Kenyan and other sub-Sahara African countries government need to come up with polices geared to supporting improvement of firms absorptive capacities so as to spur the growth of their key sectors of the economy.
\end{abstract}

Keywords: Absorptive capacity, Firm Performance, Foreign Direct Investment.

\section{INTRODUCTION}

The significance surrounding the notion of absorptive capacity in organization learning began to take recognition in the 1980s. This is evident from the numerous studies that accentuated the critical role played by application of newly found knowledge in leveraging the firm competitiveness. Early researchers like Cohen and Levinthal [1] conceptualized absorptive capacity as the potentiality of an enterprise to identify, integrate, and apply any form of external and valuable knowledge in pursuit of commercial success. Further, Kneller[2] describes absorptive capacity as the capability developed by local organizations, which is crucial for these organizations to make successful use of foreign technology.

More recently Lenart [3] defined absorptive capacity as the ability of firms to use existing information with an emphasis on their capability to transform and assimilate it together with their ability to acknowledge external knowledge as a rightful resource for innovation. Andrea and Carlos [4] supported this by defining absorptive capacity as the dynamic ability that companies had in the processes of acquiring, assimilating, transforming and applying external knowledge in the processes of enhancing their innovative processes. Research on absorptive capacity suggests that innovative organizations
Submitted : October 05, 2021

Published : October 31, 2021

ISSN: $2507-1076$

DOI: $10.24018 /$ ejbmr.2021.6.5.1134

M. D. Wanjere

PhD Candidate, University of Nairobi, Kenya.

(e-mail: mdwanjere@gmail.com)

X. N. Iraki

School of Business, University of Nairobi, Kenya.

(e-mail: m.kinoti@uonbi.ac.ke)

M. Ogutu

3School of Business, University of

Nairobi, Kenya.

(e-mail: xniraki@ gmail.com)

M. Kinoti

School of Business, University of Nairobi,

Kenya.

(e-mail: ogutum@ ${ }^{@}$ uonbi.ac.ke)

*Corresponding Author tend to join forces with external actors in the processes of acquiring new knowledge. This may involve acquiring knowledge from external sources that are outside firms' foundations. During this process, organizations are able to improve their learning processes and competitive advantages [5].

Onyekwena [6] asserted that knowledge spillover from advanced industrial economies to developing economies require that local capabilities be present in host countries. It is also noted that foreign direct investment activity takes places within an organizational setting, such as firms. The implication of this is that the knowledge resources also referred to as absorptive capacity available within such organizations plays a significant role in facilitating successful knowledge and technology spillover from foreign firms. Lau and Lo [7] further noted that absorptive capacity is considered a crucial part of the learning system as it provides the potentiality to transform the knowledge base of an organization through acquisition, assimilation, reshaping and capitalization processes giving the firm real adaptive capacity.

The study operationalized absorptive capacity as a system constituting of firm's ability to acquire, assimilate, transform and exploit. The internal system that constitutes the absorptive capacity within firms enable firms to make use of newly developed technologies. This is in line with the 
knowledge based theory that considers knowledge as the most strategic resource and dynamic capabilities theory that stress integration, reconfiguration and renewal of resources. The study adopted the four variables of acquisition, assimilation, transformation and exploitation to operationalize absorptive capacity.

\section{A. Kenya's Manufacturing Sector}

The Kenyan manufacturing industry is part of the key agenda in the Kenya Government transformation program. With a GDP contribution of $9.5 \%$ in 2018 , the sector is at the heart of Kenya industrialization policy and provide the best entry point for FDI. However, the level of investment realized in this sector is still very low and credit to the sector declined by $4.6 \%$ Ksh 277.4 billion in 2016 form from Ksh 290.9 billion in 2015 [8].

Despite the importance of the manufacturing sector for the Kenyan economy and the important role played by the absorptive capacity in facilitating FDI spillover, the mediating effect of absorptive capacity in the relationship between FDI and firm performance has not been systematically studied making sector a suitable for this study. The study will analyze the effect of absorptive capacity in the relationship between FDI and local firm's performance.

\section{RELATED LITERATURE}

The breadth of empirical base touching on the link between FDI and firm performance has to a large extent indicated inconclusive results attributable to isolated study of foreign direct investment and ignoring other variables that could impact the relationship. Asuantri and Yasmin [9] established that foreign direct investment and absorptive capacity have no significant effect on technological innovation when estimated separately but yields significant positive effect on technological innovation when their interaction considered. This imply that learning process occurs when local firms intermingle with MNEs and is made possible by absorptive capacity of the local firms. The position is supported by Leman and Ismet [10] study which established that innovation attributable to FDI inflows increase with increase in absorptive capacity in host countries.

Rueda and Shamsub's study (as cited in [9]) explained that countries do not achieve the same level of success in transforming technologies into innovation even where they receive the same technology. Further, they established that FDI impacted the survival of indigenous firms positively in top performing tech firms and none on those in low-tech industries meaning that local firms with relatively higher absorptive capacity gain more from FDI than other firms. Ricardo, Luisa and Simona [11] noted that foreign direct investment had positive implications on the performance of local companies and contended that the capacity of local companies to assimilate fresh knowledge was a key ingredient for them to capitalize on FDI. The efficacy levels of companies shape their absorptive capacity particularly in relation to new technology implying that the companies' ability to seamless integrate new technologies in their operations rested on their level of productivity [12].

In their work, Thorbecke and Wan [13] stressed on the gravity of building absorptive capacities in that it creates linkages and spillovers from FDIs in the economic development of East Asian countries. The lessons from several East Asian countries have shown that staff training and other education programmes ensure acquisition and application of new technology. Besides there is evidence that highlights the significance of thoughtful action to advance absorptive capacity within firms [13]. Chang, Gong, Way and Jia [14] asserted that organizational ability to learn from past experiences together with flexible staff management practices may be used to explain the differences in firms' performance. Anwar and Nguyen [15] study of the Swiss and Vietnam manufacturing respectively found proof of spillover from FDI activities to local firms with adequate levels of absorptive capacity.

Lau and Lo [7] argues that a firm must take steps aimed at enhancing absorptive capacity in order to improve its innovation performance. They noted that research and development activity is a spur for innovation industries and greater research and development investment support better adoption of new technologies in design and innovation of new products. Kneller and Stevens [16] noted that a country needs to possess sufficient levels of absorptive capacity to fully benefit from the technology content of imported intermediate inputs. Li [17] demonstrated that Chinese companies utilized local research and development efforts to drive the capacity of the local companies to integrate foreign technological know-how in their operations.

Blalock and Gertler [18] studied the Swiss manufacturing firms and found that companies with comparatively sufficient absorptive capacities were more poised to gain from spillovers. Similar evidence was adduced by Anwar and Ngueyn [15]. Codjoe [19] asserted that although local companies may face major obstacles in their ability to make huge investments in innovation and research and development activities, it is of vital importance, that an internal mechanism exist that governs the firm ability to integrate new technologies into the operations of a company. Wanjere and Yabs [20] observed that absorptive capacity is a powerful tool to upgrade the efficiency of the firms, gain more from MNES spillovers and improves their competitive advantage. Cohen and Levinthal [1] asserted that organizations that carry out their own research and development are better placed to exploit and replicate outside knowledge than companies devoid of R\&D initiatives. a and Saggi [21], and Kinoshita [22] as cited in Damgaard [23] observed that productivity spillovers and the technological gap are contrariwise associated meaning that highly productive local firms gain more from foreign direct investment.

Absorptive capacity has been progressively researched the objective of such study being the belief that positive FDI spillover to domestic economies depends on their capacity to exploit the opportunity. This reflects a promising phase for renewed interest in the uncovering of the interplay between FDI and performance, which is imperative owing to the contingency of outcomes. Therefore, these two variables can be combined to propose that foreign direct investment influences absorptive capacity that in turn influences firm's performance. From this, we can infer that absorptive capacity mediates the link between FDI and performance. 


\section{CONCEPTUAL FRAMEWORK AND HYPOTHESIS}

\section{A. Conceptual Framework}

Kombo and Tromp [24] noted that conceptual framework denotes a set of broad thoughts and values extracted from relevant spheres of study and adapted in configuring a subsequent presentation. The conceptual framework was established on a diverse theoretical underpinning including FDI theories, dynamic capabilities, knowledge based and resource dependence. The study conceptualized the link between FDI and firm performance as mediated by the absorptive capacity of the firm. The framework is illustrated in Fig. 1.

\section{B. Conceptual Hypotheses}

The study was guided by the following hypotheses:

Hypothesis: Absorptive capacity has no significant mdiating effect on the relationship between FDIs and performance of manufacturing firms in Kenya.

\section{Methodology And DAtA}

This research adopted a correlational design to evaluate relationship among variables. The study population consisted of all the 100 manufacturing firms registered with KAM and that had over $10 \%$ foreign investment in Kenya. The firm was the principal unit under investigation. The data was collected from one member of the top management preferably CEO or the finance and strategy director who were considered knowledgeable about the issue under investigation; as such, they were the key informants. Their choice is consistent with similar studies conducted by Shabarati, Jawad and Bontis [25] and Cabrita and Bontis [26] who claim top managers are knowledgeable about organizational characteristics.

Both descriptive and inferential statistics were utilized to analyze the data. Descriptive statistics was computed to represent general information and firm characteristics [27]. Additionally, a series of regression analyses was conducted to assess the relationship between the independent and dependent variables to determine whether the results are significant or not. Table I provides a summary of the hypothesis test and analytical procedures.

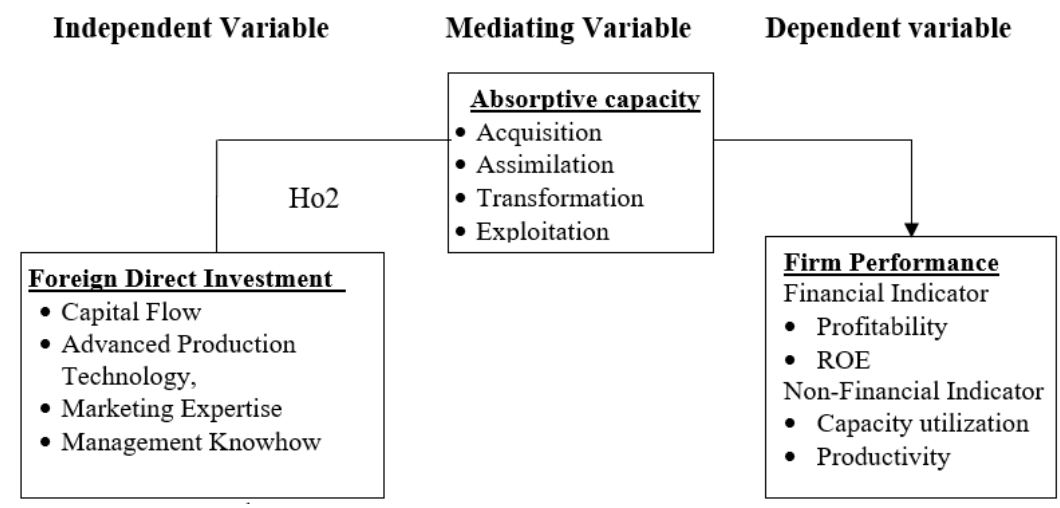

Fig. 1. Conceptual Model. Source: Researcher 2017.

TABLE I: OBJECTIVES, HYPOTHESES, TESTS AND ANALYTICAL MODELS

\begin{tabular}{|c|c|c|c|}
\hline Objective & Hypothesis & Hypothesis Test & Analytical model \\
\hline $\begin{array}{l}\text { Objective : } \\
\text { Determine the mediating role } \\
\text { of absorptive capacity on the } \\
\text { relationship between FDI } \\
\text { and } \mathrm{n} \text { firm } \\
\text { performance. }\end{array}$ & $\begin{array}{l}\text { H2: Absorptive capacity has } \\
\text { no significant } \\
\text { mediating effect on the } \\
\text { relationship } \\
\text { between FDIs and firm } \\
\text { performance. }\end{array}$ & $\begin{array}{c}\text { Mediation Methodology: (Baron and Kenny } \\
(1986) \text {. } \\
\text { Hierarchical regression analysis } \\
\text { Step } 1: \mathrm{FP}=\beta 0+\beta 1 \mathrm{FDI}+\varepsilon \\
\text { Step 2: } \mathrm{FP}=\beta 0+\beta 1 \mathrm{FDI}+\beta 2 \mathrm{AC}+\varepsilon \text { Where, } \\
\beta 0=\text { Constant, } \\
\beta 1, \beta 2=\text { Regression coefficient } \\
\mathrm{FP}=\text { Firm performance } \\
\mathrm{FDI}=\text { composite index of Foreign Direct } \\
\text { Investment } \\
\mathrm{AC}=\text { composite index of Absorptive capacity, } \\
\varepsilon=\text { Error term }\end{array}$ & $\begin{array}{c}\text { The value of adjusted } \mathrm{R}^{2} \text { will show } \\
\text { variation in firm's performance } \\
\text { explained by FDI } \\
\text { F ratio will show the overall } \\
\text { robustness and significance of the } \\
\text { model } \\
\text { Reject } \mathrm{H}_{\mathrm{o}} \text { if } \mathrm{p}>0.05 \\
\text { Some form of mediation is supported } \\
\text { when FDI is no longer significant } \\
\text { when AC is controlled }\end{array}$ \\
\hline
\end{tabular}

\section{PRELIMINARY ANALYSis}

\section{A. Diagnostic Test}

The data was checked for normality and multicollinearity before proceeding with regression analysis. The model must meet the conditions of normal distribution and absence of multicollinearity. Violation of these assumptions puts the researcher at the risk of producing misleading estimates [28].

\section{1) Normality Tests}

Normality test is used to assess whether data matches a normal distribution. Variables that exhibit significant deviations from normality are likely to alter relationships.
McCabe, Moore and Craig [29] posited that the tests for normality is very essential in determining whether or not the data collected was modelled properly by a normal distribution. Normality of data was established using histograms. Miot [30] posited that a good and decent data used in research is that which can be said to be normally distributed. The results of the normality test are presented in the proceeding section.

\section{1) Histogram Graphs for Normality of Responses}

\subsection{1) Foreign Direct Investment}

Fig. 2 displays a symmetrical histogram, an indication that FDI was normally distributed. Specifically, the variable followed a normal distribution with a mean equal to 2.46 and 
standard deviation of 0.311 . As such, it was concluded that the foreign direct investment variable met the normality condition.

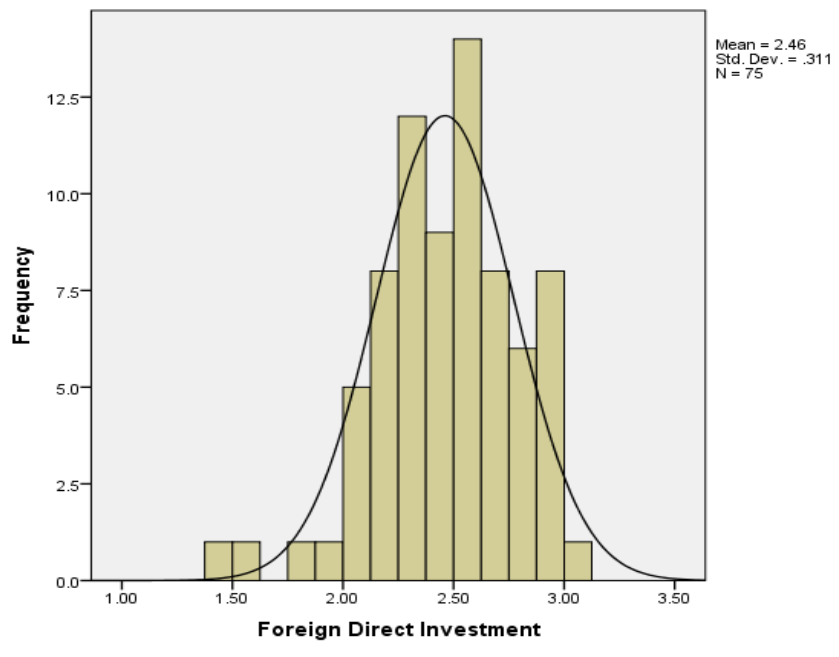

Fig. 2. Histogram of Foreign Direct Investment. Source: Field Data 2019.

\subsection{2) Absorptive Capacity}

Fig. 3 is a symmetrical histogram indicating that the mediating variable absorptive capacity provided responses that upon exploring for normality showed that the distribution of responses for the variable was normal or bell-shaped with a mean equal to 3.81 and standard deviation of 0.507 . It was thus concluded that the absorptive capacity variable fulfilled the normality pre-condition.

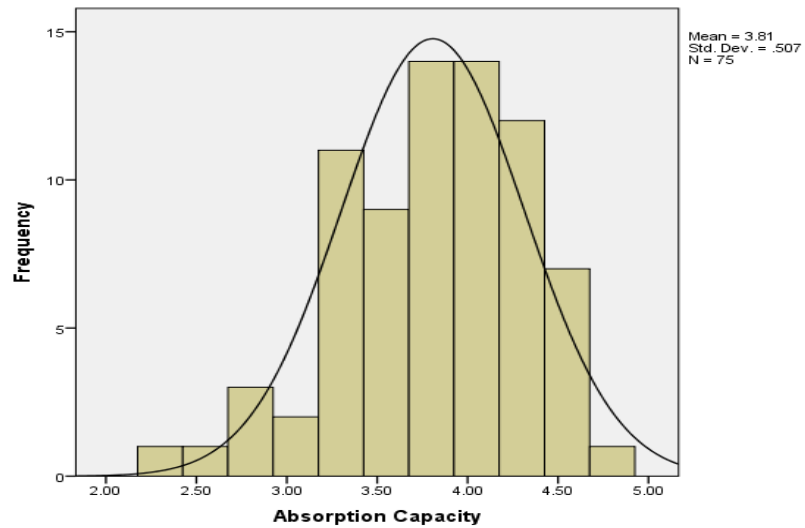

Fig. 3. Histogram of Absorptive Capacity. Source: Field Data 2019.

\subsection{3) Manufacturing Performance}

The manufacturing performance variable was investigated for normality using histogram and results of analysis presented in Fig. 4 below.

Fig. 4 is a symmetrical histogram indicating that the independent variable Manufacturing Performance was normally distributed as the histogram was bell-shaped with a mean equal to 2.77 and standard deviation of 0.52 .

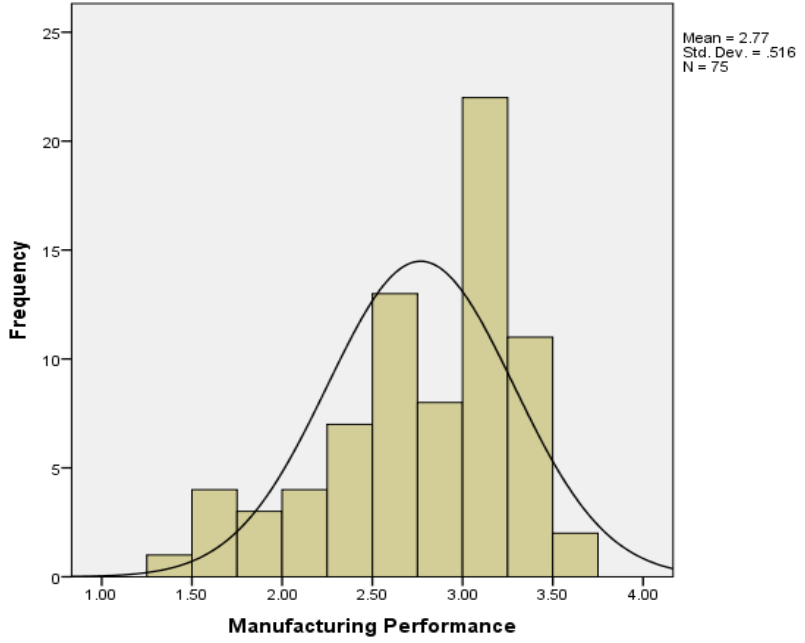

Fig. 4. Histogram Of Firm Performance. Source: Field Data 2019.

\section{2) Multicollinearity Test}

Multicollinearity occurs when there are multiple explanatory variables that exhibit high degree of correlations [31], [32]. To check for this precondition, the variance inflation factor (VIF) test was invoked with a VIF exceeding 10 indicating multicollinearity [33].

TABLE II: COLLINEARITY STATISTICS

\begin{tabular}{ccc}
\hline \multirow{2}{*}{ Variable } & \multicolumn{2}{c}{ Collinearity Statistics } \\
\cline { 2 - 3 } & Tolerance & VIF \\
\hline Foreign Direct Investment & 0.984 & 1.016 \\
Absorption Capacity & 0.988 & 1.012 \\
\hline
\end{tabular}

Dependent Variable: "Manufacturing Performance.

Source: Field Data (2019)

Table II shows that for the two variables of interest, the VIF ranged from 1.012 to 1.016 . The values being more than 1 and less than 10 indicate that there was absence of multicollinearity. Additionally, the tolerance values for all the variables ranged from 0.984 to 0.988 further confirming nonviolation of the precondition.

\section{3) Homogeneity Tests}

Homoscedasticity assumption means that standard deviation and variance of errors about the regression line is unvaried for all the explanatory variables [34]. The levene test was used to assess this precondition by examining whether or not there is no equality in the variances of the two populations is true [33]. The test was done on a 5\% significance level and results are as shown in Table III.

\begin{tabular}{ccccc}
\multicolumn{5}{c}{ TABLE III: LEVENE TEST STATISTICS } \\
\hline Variable & Levene Statistic & df1 & df2 & Sig. \\
\hline Foreign Direct & 2.733 & 12 & 58 & 0.005 \\
Investment & 1.110 & 12 & 58 & 0.370 \\
Absorption Capacity & & & &
\end{tabular}

Table III shows that out of the two variables, only absorption capacity had a $p$-value greater than 0.05 . Therefore, the null hypothesis that the data for absorption capacity did not fulfil the homoscedasticity condition was rejected. It was also concluded on the basis of the $p$-values that foreign direct investment did not meet the precondition. 


\section{B. Descriptive Statistics}

Descriptive statistics were useful in this study as they presented quantitative data in a manageable form. The findings are presented in the next section.

\section{1) Foreign Direct Investment}

In this study FDI was conceptualised using four variables namely: capital flow, advanced production technology, marketing expertise and management knowhow as guided by Muhammad and Kashif [35] and Leman and Ismet [10]. The respondents were required to respond by indicating if FDI introduction led to certain activities associated with the capital flow, advanced production technology, marketing expertise and management knowhow in their organizations. The findings are presented in Table IV.

\begin{tabular}{|c|c|c|c|c|c|}
\hline Variables & $\mathrm{N}$ & Mean & $\begin{array}{c}\text { Std. } \\
\text { Deviatio } \\
\mathrm{n}\end{array}$ & $\begin{array}{c}\text { Varianc } \\
\mathrm{e}\end{array}$ & $\mathrm{CV}$ \\
\hline Capital Flow & 75 & 2.68 & 0.70 & 0.49 & 0.26 \\
\hline $\begin{array}{l}\text { Advanced } \\
\text { production } \\
\text { Technology }\end{array}$ & 75 & 2.31 & 0.86 & 0.75 & 0.38 \\
\hline Marketing Expertise & 75 & 2.43 & 0.86 & 0.76 & 0.31 \\
\hline $\begin{array}{l}\text { Management } \\
\text { Knowhow }\end{array}$ & 75 & 2.46 & 0.86 & 0.74 & 0.30 \\
\hline Overall FDI & 75 & 2.47 & 0.82 & 0.685 & $\begin{array}{c}0.312 \\
5\end{array}$ \\
\hline
\end{tabular}

The overall ranking for FDI was a mean score of 2.47, std deviation of 0.82 , variance of 0.68 and $\mathrm{CV}$ of 0.3125 . On specific variable, the highest ranked was capital flow with a score (mean scores above 2.68, standard deviation of 0.70 , Variance of 0.49 and CV of 0.026 ), followed by management knowhow with scores of (mean scores of 2.46, standard deviation of 0.86 , Variance of 0.7 and $\mathrm{CV}$ of 0.30 ), them marketing expertise with mean scores above 2.43, standard deviation of 0.86 , Variance of 0.7 and $\mathrm{CV}$ of 0.31 ) and finally advanced production technology with a scores of (mean scores above 2.31, standard deviation of 0.86 , Variance of 0.7 and $\mathrm{CV}$ of 0.38 ).

\section{2) Absorptive Capacity}

This represents the dynamic ability that companies have in the processes of acquiring, assimilating, transforming and applying external knowledge to enhance their innovative processes [4]. Onyekwena [6] noted that this capacity is critical for successful transmission of know-how from industrialized nations to less developed countries. Absorptive capacity was postulated as the mediator in the model and was measured using four variables of acquisition, assimilation, transformation and exploitation. The results are presented on the table below:

TABLE V: ABSORPTION CAPACITY

\begin{tabular}{cccccc}
\multicolumn{7}{c}{ TABLE V: ABSORPTION CAPACITY } \\
\hline & $\mathrm{N}$ & Mean & $\begin{array}{c}\text { Std. } \\
\text { Deviatio } \\
\mathrm{n}\end{array}$ & Variance & $\begin{array}{c}\text { Coefficient } \\
\text { of Variation }\end{array}$ \\
\hline Acquisition & 75 & 3.70 & 1.12 & 1.28 & 0.35 \\
Assimilation & 75 & 3.76 & 1.08 & 1.18 & 0.32 \\
Transformation & 75 & 3.71 & 0.96 & 0.97 & 0.27 \\
Exploitation & 75 & 4.06 & 0.90 & 0.81 & 0.20 \\
& 75 & 3.81 & 1.02 & 1.06 & 0.29 \\
\hline
\end{tabular}

Source: Field Data (2019).
The overall ranking for absorptive capacity was a mean score of 3.81, standard deviation of 1.02 , variance of 1.06 and $\mathrm{CV}$ of 0.29 . On specific variable, the highest ranked was exploitation with a score (mean scores 4.06, standard deviation of 0.90 , Variance of 0.81 and $\mathrm{CV}$ of 0.20 ), followed by assimilation with (mean scores 3.76 , standard deviation of 1.08, Variance of 1.18 and CV of 0.32), then transformation with mean scores .3 .71 , standard deviation of 0.96 , Variance of 0.97 and $\mathrm{CV}$ of 0.27 ) and finally acquisition with a scores of (mean scores above 3.70, standard deviation of 1.12, Variance of 1.28 and $\mathrm{CV}$ of 0.35 ).

\section{3) Regression Analysis}

The researcher set out to test the effect of absorptive capacity on the relationship between FDI and performance of manufacturing firms. The study developed a hypothesis and was tested using simple linear regression analysis. The results from the test of hypothesis are presented in the preceding section.

3.1) The Mediating Role of Absorptive Capacity on FDI and Performance of Manufacturing Firm

As pertains to the objective, the intended goal was to investigate whether intervening force of absorptive capacity would be found operative in the link between FDI and performance. A corresponding hypothesis was put forward which held the following statement:

$H_{02}$ : Absorptive capacity does not have a statistically significant mediating influence on the relationship between FDI and performance of manufacturing firms in Kenya.

The mediating role of absorptive capacity was examined through hierarchical regression models. In the first model, the link between FDI and performance was established. The second model assessed whether or not the combined effect of FDI and absorptive capacity on performance was statistically valid. Manifestation of the intervening forces of absorptive capacity would be attested if the change in $\mathrm{R}^{2}$ would be found to be significant.

The coefficients of determination for the first and second model were 0.079 and 0.086 , respectively. The implication is that FDI together with absorptive capacity accounted for 8.6 percent change in performance. The associated change in $\mathrm{R}^{2}$ was thus 0.007 , which was significant. The results further show that overall significance of the model with mediating effects indicated a p-value of 0.039 which was less than 0.05 and on the basis of these results, the hypothesis is not supported and is therefore rejected. It was thus concluded that absorption capacity had a statistically significant mediating effect in the relationship between FDI and performance. As such, the findings were indicative that the intervening forces of absorptive capacity in the link between FDI and performance were operative. The results of these models are illustrated in Table VI. 
TABLE VI: THE MEDIATING ROLE OF ABSORPTIVE CAPACITY ON FDI AND PERFORMANCE Model Summary

\begin{tabular}{|c|c|c|c|c|c|c|c|c|c|}
\hline \multirow{2}{*}{ Model } & \multirow{2}{*}{$\mathrm{R}$} & \multirow{2}{*}{ R Square } & \multirow{2}{*}{$\begin{array}{l}\text { Adjusted R } \\
\text { Square }\end{array}$} & \multirow{2}{*}{$\begin{array}{l}\text { Std. Error of the } \\
\text { Estimate }\end{array}$} & \multicolumn{5}{|c|}{ Change Statistics } \\
\hline & & & & & R Square Change & F Change & df1 & df2 & Sig. F Change \\
\hline 1 & $0.281^{\mathrm{a}}$ & 0.079 & 0.067 & 0.49882 & 0.079 & 6.282 & 1 & 73 & 0.014 \\
\hline 2 & $0.293^{\mathrm{b}}$ & 0.086 & 0.060 & 0.50047 & 0.007 & 0.521 & 1 & 72 & 0.473 \\
\hline
\end{tabular}

a. Predictors: (Constant), Foreign Direct Investment

b. Predictors: (Constant), Foreign Direct Investment, Absorption Capacity

\begin{tabular}{|c|c|c|c|c|c|c|}
\hline \multicolumn{7}{|c|}{ ANOVA $^{\mathrm{a}}$} \\
\hline & Model & $\begin{array}{l}\text { Sum of } \\
\text { Squares }\end{array}$ & df & Mean Square & $\mathrm{F}$ & Sig. \\
\hline \multirow{3}{*}{1} & Regression & 1.563 & 1 & 1.563 & 6.282 & $0.014^{\mathrm{b}}$ \\
\hline & Residual & 18.164 & 73 & 0.249 & & \\
\hline & Total & 19.727 & 74 & & & \\
\hline \multirow{3}{*}{2} & Regression & 1.694 & 2 & 0.847 & 3.381 & $0.039^{c}$ \\
\hline & Residual & 18.034 & 72 & 0.250 & & \\
\hline & Total & 19.727 & 74 & & & \\
\hline
\end{tabular}

a. Dependent Variable: Manufacturing Performance

b. Predictors: (Constant), Foreign Direct Investment

c. Predictors: (Constant), Foreign Direct Investment, Absorption Capacity

Source: Field Data (2019).

A breakdown of the regression coefficients for the two models is reported in Table VI. The table vi shows that in the model capturing the link between FDI and performance, the coefficient for FDI was positive and significant $\left(\beta_{1}=0.479\right.$, $\mathrm{p}$-value $=0.013$ ). This was an indication that unit increment in FDI would improve performance by $46.7 \%$. In connection to the second model, the coefficients associated with the contributory factors of FDI and absorptive capacity were $0.479(p<0.013)$ and $-0.83(p<0.473)$, respectively. These results suggest that controlling for absorptive capacity, there would still be a positive and significant link between FDI and performance, where a unit increment would elevate performance by $47.9 \%$. This is presented in table vii below:

TABLE VII: REGRESSION COEFFICIENTS OF FDI AND ABSORPTIVE

\begin{tabular}{|c|c|c|c|c|c|}
\hline \multicolumn{6}{|c|}{ CAPACITY } \\
\hline \multicolumn{6}{|c|}{ Coefficients } \\
\hline \multirow{2}{*}{ Model } & \multicolumn{2}{|c|}{$\begin{array}{l}\text { Unstandardized } \\
\text { Coefficients }\end{array}$} & \multirow{2}{*}{$\begin{array}{c}\begin{array}{c}\text { Standardized } \\
\text { Coefficients }\end{array} \\
\text { Beta }\end{array}$} & \multirow{2}{*}{$\mathrm{T}$} & \multirow{2}{*}{ Sig. } \\
\hline & B & $\begin{array}{c}\text { Std. } \\
\text { Error }\end{array}$ & & & \\
\hline (Constant) & 1.618 & 0.462 & \multirow{3}{*}{0.281} & 3.500 & 0.001 \\
\hline \multicolumn{2}{|c|}{ Foreign Direct Investment 0.467} & 0.186 & & 2.506 & 0.014 \\
\hline (Constant) & 1.905 & 0.611 & & 3.117 & 0.003 \\
\hline${ }_{2}$ Foreign Direct Investmer & t 0.479 & 0.188 & 0.289 & 2.552 & 0.013 \\
\hline Absorption Capacity & $\overline{-}-$ & 0.115 & -0.082 & -0.722 & 0.473 \\
\hline
\end{tabular}

Source: Field Data (2019).

\section{Discussion of Results}

1) FDI, Absorptive Capacity and Performance of Manufacturing Firms

A central proposition advanced in this study was that there are intervening forces that could potentially reinforce or inhibit the link between FDI and performance of companies. One of these forces was identified to be absorptive capacity. Against this backdrop, the second objective set out to explore whether or not there was any attestation that the intervening forces of absorptive capacity were operative in the relationship.

The findings for firm performance produced $\mathrm{R}^{2}=0.086, \mathrm{~F}$ $=6.282, \beta=0.479 \mathrm{t}=3.5, \mathrm{p}>.05$. This implies that absorptive capacity had significant and positive relationship with firm performance. Thus, organizations that want to improve their performance by appropriating the benefits of FDI can invest on their absorptive capacity factors by allocating resources to support acquisition, assimilation, exploitation and ensure transformation of ideas.

The findings of this study support Asuantri and Yasmin [9] that established that absorptive capacity interaction with FDI inflows have significant effect on technological innovation and subsequent performance of the firm. The outcome of the current research is also consistent with the study of Leman and Ismet [10] which found that FDI inflows improves the level of innovation with upsurge in absorptive capacity in host economies. The current findings is also consistent with Ricardo, Luisa and Simona [11] which noted that FDI influenced the outcomes of domestic firms positively and that that the capacity of domestic firms to absorb fresh knowledge was important condition for them to benefit from FDI. The findings also agree with Pedro, Jorge and Jose [36] whose study on the implications of foreign capital on Spanish manufacturing firms and established that FDI had positive spillovers on domestic organizations and they attributed this to the absorptive capacity and foreign capital were large enough, they promoted technical progress.

This study adds to the expanding body of literature linking absorptive capability of companies and their performance. The dynamic capability theory emphasized the organization's ability to organize resources, change them as situations require, and adapt to new environments. The findings of this study further support Blalock and Gertler [18] who verified that companies that possess a highly qualified set of employees benefit significantly more in their interaction with foreign companies. The study also agrees with Hamida and Piscitello [37]; Anwar and Nguyen [15] study of the Swiss and Vietnam manufacturing respectively who noted that companies that demonstrate high-level absorptive capability are more set to benefit from the spill overs emanating from FDI activities.

\section{CONCLUSION}

The study purposed to establish the mediating influence of absorptive capacity on the association between FDI and performance. Absorptive capacity was operationalized as constituting acquisition, assimilation, transformation and 
exploitation. The outcome provided satisfactory evidence to infer that there is a link between FDI and performance, FDI and absorptive capacity, absorptive capacity and performance and controlling for the former, produced significant impacts on performance. On the grounds of these findings, it can be concluded that the intervening forces of absorptive capacity were present in the link between FDI and performance.

The study affirmed that Absorptive capacity intervenes the association between FDI and performance. The results imply that absorptive capacity is necessary if a firm is to fully tap the benefits of FDI and thus managers should invest in the absorptive capacity of their firms. Firms need strong dynamic capabilities to appropriate existing foreign firm's resources into usable applications among the local firms. The management of local firms should improve their firm's abilities by promoting learning culture which in turn will support technology and knowledge transfer.

This study contributes to the growing body of literature on the role of absorptive capacity in the relationship between FDI and firm performance. Kenyan and Sub-Sahara Africa countries policy makers are informed by the findings of this study that absorptive capacity is an important ingredient in enabling the spillovers from foreign to local firms. Therefore, there is a need to continue improving the firm's absorptive capacity to facilitate this spillover.

\section{ACKNOWLEDGEMENTS}

We wish to profoundly acknowledge the organizations that made the access of data possible namely the Kenya Association of Manufacturer and Kenya Export Promotion Center. In this regard, a special mention goes and the many manufacturing firms that participated in the study. We thank you all!

\section{REFERENCES}

[1] W. M. Cohen, D. A. Levinthal, "Absorptive capacity: A new perspective on learning and innovation," Administrative science quarterly. Ithaca, vol. 35, Issue. 1, pp. 128-152, 1990.

[2] R. Kneller, "Frontier Technology, Absorptive Capacity and Distance," Oxford Bulletin of Economics and Statistics, vol. 67(1), pp. 1-23, 2005.

[3] R. Lenart, "Operationalization of Absorptive Capacity," International Journal of Contemporary Management, vol. 1(3), pp. 86-98, 2014.

[4] H. Andrea, H. G. Carlos, "Measurement of knowledge absorptive capacity: An estimated indicator for the manufacturing and service sector in Colombia," Revista Journal of Globalization, Competitiveness \& Governability, Georgetown University, vol. 9 (2), pp. 16-42, 2015.

[5] K. Laursen, A.J. Salter, "The paradox of openness: Appropriability, external search and collaboration," Research Policy, vol. 43, pp.867878, 2014.

[6] C. Onyekwena, "Empirical investigation of the impact of Foreign Direct Investment on manufacturing firms and banks in Nigeria," Unpublished PhD Thesis, University of Portsmouth Pallant, J. (2005). SPSS Survival Manual: A Step by Step Guide to Data Analysis Using SPSS for Windows (V.12), 2012.

[7] A. Lau, W. Lo, "Regional innovation system, absorptive capacity and innovation performance: An empirical study," Technological Forecasting and Social Change, vol. 92, pp. 99-114, 2015.

[8] Kenya National Bureau of Statistics, 2017. Economic survey report 2017.

[9] M. Asuantri, B. Yasmin, "Foreign Direct Investment, absorptive capacity and technological innovation: Empirical evidence in developing economies," Global conference on business \& economics research. 2017. Online www.econ.upm.edu.my.

[10] E. Leman, G. Ismet, "The Effects of Foreign Direct Investment on R\&D and Innovations: Panel Data Analysis for Developing Asian
Countries. World Conference on Technology, Innovation and Entrepreneurship," Procedia-Social and Behavioral Sciences, vol. 195 pp. 749-758, 2015. Online at www.sciencedirect.com

[11] C. Ricardo, G. Luisa, I. Simona, "Foreign Multinationals and domestic innovation: intra-industry effects and firm heterogeneity," Research Policy, vol. 44 (3). pp. 596-609, 2015.

[12] P. S. Ilboudo, "Foreign Direct Investment and Total Factor Productivity in the Mining Sector: The case of Chile," Economics Honors Papers, 18, 2014.

[13] E. Thorbecke, H. Wan, "Revisiting East (and South East) Asia's Development Model," Paper prepared for the Cornell Conference on Seventy Five Years of Development, Ithaca, NY, May 7-9, 2004.

[14] S. Chang, Y. Gong, S.A. Way, L. Jia, "Flexibility-oriented HRM systems, absorptive capacity, and market responsiveness and firm innovativeness," Journal of Management, vol. 39(7), pp.1924-1951, 2013.

[15] S. Anwar, L. P. Nguyen, "Foreign direct investment and economic growth in Vietnam," Asia Pacific Business Review, vol. 16(1-2), pp. 183-202, 2010.

[16] R. Kneller, P.A. Stevens, Frontier technology and absorptive capacity: evidence from OECD manufacturing industries, Oxf. Bull. Econ. Stat, 68 (1), 2006

[17] X. B. Li, "Sources of external technology, absorptive capacity, and innovation capability in Chinese state-owned high-tech enterprises," World Development, vol. 39(7), pp. 1240-8, 2011.

[18] G. Blalock, P.J. Gertler, "Learning from exporting revisited in a less developed setting," Journal of Development Economics, vol. 75, issue 2, pp. 397-416, 2004.

[19] E. A. Codjoe, Foreign Direct Investment in Ghanaian Manufacturing: Exploring the Extent of Technology Transfer and Exporting Behaviour by FDI Firms. PhD Thesis, School of Oriental and African Studies (Unpublished $\mathrm{PhD}$ Thesis), 2012.

[20] M. D. Wanjere, J. Yabs, "A critical literature review on the link between Multinational Enterprises presence, Absorptive capacity and Competitive advantage of Firms," Archives of Business Research, vol. 5(3), pp. 101-114, 2017.

[21] A. J. Glass and K. Saggi, "International technology transfer and the technology gap," Journal of Development Economics, vol. 55, Issue 2 , April 1998, pp. 369-398, 1998

[22] Kinoshita, R\&D and technology spillovers through FDI: innovation andabsorptive capacity, University of Michigan William Davidson Institute Working Paper, No. 2775, 2001.

[23] J. Damgaard, Measuring FDI \& its Impact on the Danish Economy; unpublished $\mathrm{PhD}$ Thesis, University of Southern Denmark, 2011.

[24] D. K. Kombo, L. A. Tromp, Proposal and thesis writing: An introduction. Nairobi: Paulines publications Africa, 2009.

[25] A. Shabarati, J. Jawad, N. Bontis, "Intellectual capital and business performance in pharmaceutical sector of Jordan," Management Decision Journal, vol. 48 (1), pp. 105-13, 2010.

[26] R. Cabrita, N. Bontis, "Intellectual capital \& business performance in Portuguese banking industry," International Journal of Technology Management, vol. 43, pp. 212-237, 2008.

[27] C. R. Kothari, Research Methodology: Methods and Techniques. New Delhi, India: New Age International Publishers. Second revised edition, 2014.

[28] C. Brooks, Univariatetime series modelling and forecasting, Introductory Econometrics for Finance. 2nd Ed. Cambridge University Press. Cambridge, Massachusetts, 2008.

[29] G. P. McCabe, D. S. Moore, B.A. Craig, Introduction to the practice of statistics. 8. ed. New York, NY: W.H. Freeman and Co, 2014.

[30] H. A. Miot, "Assessing Normality of Data in Clinical and Experimental Trials," Journal Vascular Brasileiro , vol. 16(2), 2017.

[31] O. M. Mugenda, A. G. Mugenda, Research Methods. Quantitative and Qualitative Approaches. Nairobi: African Centre for Technology StudiesPress, 2003.

[32] L. R, Zientek, N. Kim, K. Amanda, „All Possible Subjects for MANOVA and Factorial MANOVAs: Less than a Weekend Project," International Journal of Adult Vocational education and technology, vol. 7 (2), 2016.

[33] J. F. Hair, R. E. Anderson, R. L. Tatham, W.C. Black, Multivariate data analysis, 5th Edition, Upper Sadddle River: NJ, Prentice Hall, 2008.

[34] B. G. Tabachnick, L.S. Fidell, Using multivariate statistics, (6 ${ }^{\text {th }}$ ed.) Boston: Pearson, 2013

[35] T. M. Muhammad, R. Kashif, "Does Foreign Direct Investment Influence Economic Growth and Human Capital of Host Countries? A Review of Empirical Evidence," World Applied Sciences Journal, vol. 21 (8), pp. 1116-1121, 2013. 
[36] S.S. Pedro, R.M. Jorge, G.G.V. Jose, "Absorptive capacity from FDI in Spanish Manufacturing firms," International Business Review, Elsevier, vol. 23(2),pp. 429-439, 2014.

L.B. Hamida, L. Piscitello, "The impact of foreign Research and Development activities on the MNC's performance at home: evidence from the case of Swiss manufacturing firms", retrieved from Revue d'économieindustrielle URL: http://journals.openedition.org/rei/5613, 2013. 